\title{
Cytological and Histopathological Findings of Nasal Transmissible Venereal Tumour in a Dog
}

\author{
M. Buragohain ${ }^{1 *}$ and S. Goswami ${ }^{2}$ \\ ${ }^{1}$ Department of Veterinary Pathology, College of Veterinary Science, Assam Agricultural \\ University, Khanapara, Guwahati-781022, India \\ ${ }^{2}$ Teaching Veterinary Clinical Complex, College of Veterinary Science, Assam Agricultural \\ University, Khanapara, Guwahati-781022, India
}

*Corresponding author:

\section{A B S T R A C T}

\begin{tabular}{|l|}
\hline Ke y w o r d s \\
Dog, Cytology, \\
Histopathology, \\
Transmissible \\
Venereal Tumour \\
\hline Article Info \\
\hline $\begin{array}{l}\text { Accepted: } \\
\text { 15 May 2019 } \\
\text { Available Online: } \\
\text { 10 June 2019 }\end{array}$ \\
\hline
\end{tabular}

A six years old male local dog was presented to the Teaching Veterinary Clinical Complex (TVCC), Guwahati, Assam, with the history of anorexia and presence of a big mass over the nostril and forehead. Clinically, the swelling was extending upto the base of the eyes in both the directions with discharge of blood tinged fluid from a small orifice. On fine needle aspiration cytology (FNAC), tumour cells were round to ovoid in shape with prominent nucleoli and punctate vacuoles in the cytoplasm. In histopathological examination, hypercellularity and division of cells into different pockets by irregular fibrous connective tissue stroma were well demonstrated. The case was diagnosed as extragenital transmissible venereal granuloma based on cytological and histopathological findings.

\section{Introduction}

Transmissible venereal tumour (TVT) is one of the most common round cell neoplasms of canines. Canine TVT, is also called as infectious sarcoma, venereal granuloma, transmissible lymphosarcoma or Sticker's tumour. TVT is a reticuloendothelial tumour of dogs which affects external and internal genitalia of both the sexes (Goldschmidt and Hendrick, 2002). The tumour is mainly transmitted through coitus but animal behaviour such as sniffing, licking or scratching of the affected area also leads to transmission of the tumour to other areas (UmaRani and Pazhanivel, 2015). Freeroaming, sexually mature, stray and active dogs are more prone to TVT. Fine needle aspiration cytology (FNAC) is a fast and noninvasive method, widely used by clinical laboratories to diagnose different neoplastic conditions before the surgical intervention. FNAC can be used for diagnosis of subcutaneous and other tumours and also for body cavity effusions (Pavel et al., 2016). FNAC is also widely used for easy and early 
diagnosis of canine TVT (Rocha et al., 2014). Histopathogical examination of the tumour mass reveals typical TVT cells which gives the definitive diagnosis of the disease (Ojeda et al., 2018). This case revealed presence of primary extra genital tumours in the nasal and frontal area and diagnosis of the case is made on the basis of cytological examination of FNAC material followed by histopathology.

A six years old male local dog was presented to the Teaching Veterinary Clinical Complex (TVCC), College of Veterinary Science, AAU, Guwahati, Assam, with the history of anorexia and presence of a big mass over the nostril and forehead. Clinical examination of the animal, revealed an irregularly large mass of tissue in the nasal and forehead area which was extending upto the base of the eyes in both sides. Soft tissue mass has been observed through a small opening in the tumour through which blood tinged fluid are coming out. Internally, fluid pockets were seen in the nasal orifices which are thought to be formed as a result of wiping of fluids from the tumour mass. A smear was prepared for cytological examination, in a grease free glass slides from the sample obtained by fine needle aspiration. A part of the growth was removed by surgical excision using local anaesthesia surrounding the tumour mass for histopathological examination. On gross examination, the tissue was soft, pink and irregular in shape. A piece of the tissue was collected in 10 percent formalin solution for histopathological examination.

After proper fixation, tissue sample was washed overnight in running tape water, dehydration in ascending grades of alcohol followed by clearing in xylene and paraffin embedding as per the standard protocol. The embedded tissue is than cut into $4-5 \mu \mathrm{m}$ thickness with a rotary microtome and stained with routine $\mathrm{H} \& \mathrm{E}$ stain for histopathological examination. For cytological examination, the smear was fixed in methanol, air dried and stained with Giemsa.

Fig.1 Nasal cytology smears showing the round cells with punctate cytoplasmic vacuoles, prominent nuclei and coarse chromatin pattern

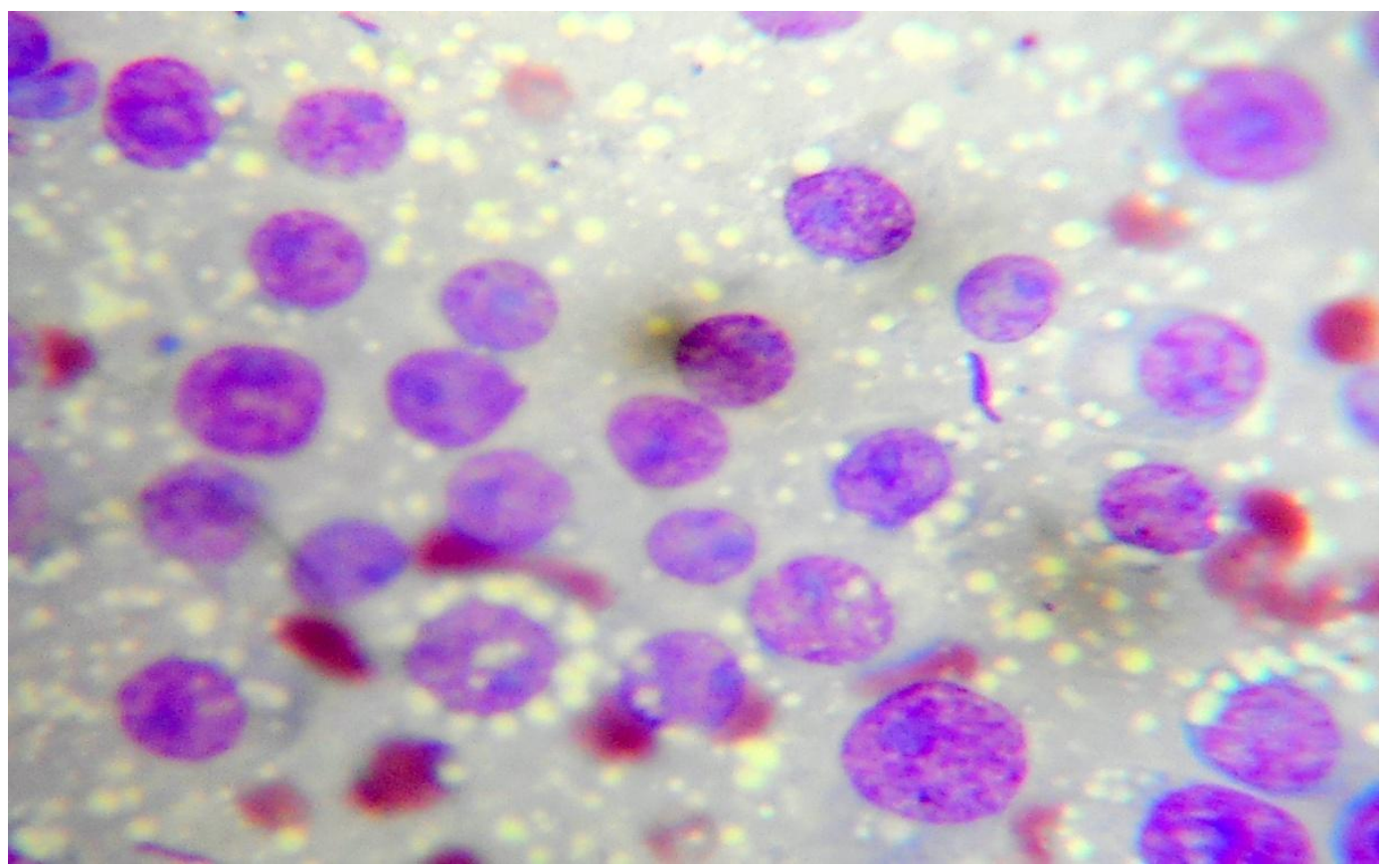


Fig.2 Histopathology showing proliferation of pleomorphic cells separated by fibrovascular stroma with large prominent nucleus and large ovoid nucleoli

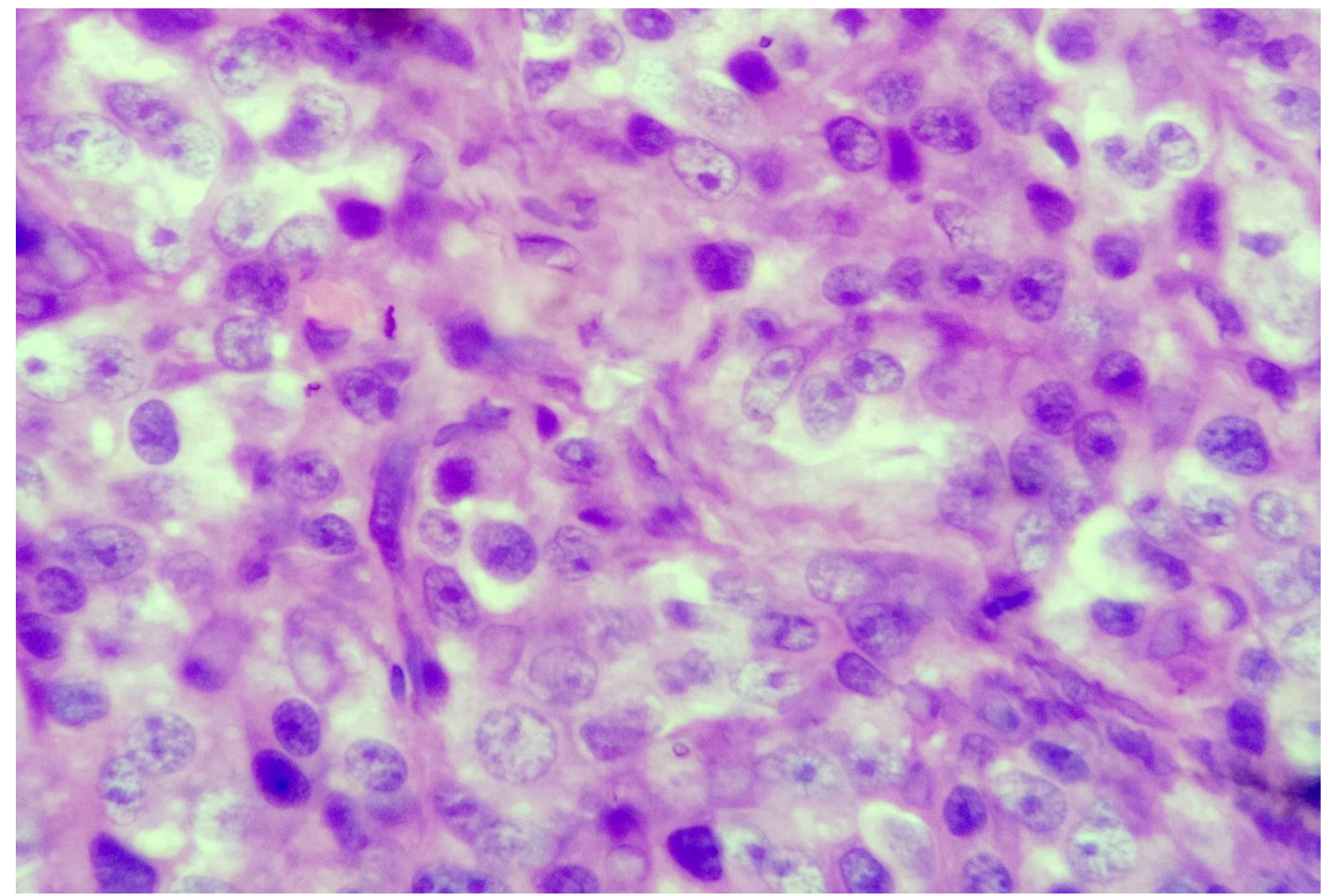

Cytological examination of nasal smear revealed, presence of large numbers of round to ovoid cells with punctate vacuoles in the cytoplasm. The nuclear and cytoplasm ratio is found to be increased and few mitotic figures were observed in the nucleus of the cells. Other cytological changes include clumping of chromatin material which leads to granular appearance of the karyoplasms and prominent nucleoli (Fig. 1). In histopathological examination, the section of the tumour mass showed hypercellularity with round cells which were divided into different pockets by irregular distribution of thin fibrous connective tissue stroma. The cytoplasms of the cells are basophilic in clolour with prominent nucleus (Fig. 2). This case was diagnosed as extragenital TVT based on the characteristic cytological and histopathological findings and which can be clearly differentiated from other nasal tumours. In the present case development of tumour in the extragenital area, is might be due to sniffing or licking the genitalia of other affected animals. This is in accordance with other researchers (Raghunath et al., 2015). In cytology, TVT cells were observed with vacuoles in the cytoplasm. Similar findings were reported by earlier workers in extra genital type of canine TVT (Amaral et al., 2007). FNAC is found to be reliable for early detection of TVT as it is easy to perform, less time consuming, do not required sophisticated laboratory involvement and it maintains the normal cell morphology. Previous workers also performed FNAC for diagnosis of TVT (Chowdary et al., 2016). In histopathology, TVT cells were observed as round to oval with mitotic figures in the nucleus which helps in confirmatory diagnosis of the disease. 
Similar findings were observed by earlier workers (Chikweto et al., 2013).

FNAC can be widely used as a reliable diagnostic method in the clinical laboratory for early diagnosis of TVT, as it is simple, easy, fast, and inexpensive which allows study of cell morphology. FNAC should be followed by histopathology for confirmatory diagnosis of TVT.

\section{References}

Amaral, A.S., Silva, S.B., Ferreira, I, Fonseca, L.S., Andrade, F.H.E., Gaspar, L.F.J. and Rocha, N.S. 2007. Cytomorphological characterization of transmissible canine veneral tumor. RPCV, 102: 253-260.

Chikweto, A., Kumthekar, S., Larkin, H., Deallie, C., Tiwari, K.P., Sharma, R.N., and Bhaiyat, M.I. 2013. Genital and Extragenital Canine Transmissible Venereal Tumor in Dogs in Grenada, West Indies. Open Journal of Veterinary Medicine. 3:111-114.

Chowdary, S.R., Raghunath, M., Sagar, P.V., Sailaja, B., Ravi Kumar, P., and Hari Krishna, N.V.V. 2016. Cytomorphology of canine transmissible venereal tumors. International Journal of Science, Environment and Technology. 5(4): $2239-2244$.

Goldschmidt, M.H., and Hendrick, M.J. 2002.
Tumours of the skin and soft tissues. In: Tumours in Domestic Animals. (Meuton, D. J., Ed.), 4th ed., Iowa State Press, Iowa, Pp: 45-118.

Ojeda, J., Mieres, M., Soto, F., Arnes, V., Paredes, E., and Navarrete, M. 2018. Computer tomographic imaging in 4 dogs with primary nasal canine transmissible venereal tumor and differing cellular phenotype. $\mathrm{J}$ Vet Intern Med. 00:1-6.

Pavel, G., Malancus, R., and Condrea, M. 2016. Fine Needle Aspiration Cytology (FNAC) of Neoplasms in Dogs and Cats, with Emphasis on Differential Diagnosis - A Retrospective Study, Bulletin UASVM Veterinary Medicine 73(1): 116-126.

Raghunath, M., Chowdhary, S.R., and Vidya Sagar, P. 2015. Genital and extra genital TVT in a bitch- a case report, Sch J Agric Vet Sci. 2(1B):61-62.

Rocha, N. S., Tremori, T.M., and Carneiro, J.A.M. 2014. Fine needle aspiration cytology in the diagnosis of canine cutaneous transmissible venereal tumor - case report. Open Journal of Veterinary Medicine. 4: 204 -209.

Uma Rani, R., and Pazhanivel, N. 2015. Rare cases of primary canine extragenital transmissible venereal tumours. International Journal of Advanced Veterinary Science and Technology. 4(1):149-152.

\section{How to cite this article:}

Buragohain, M. and Goswami, S. 2019. Cytological and Histopathological Findings of Nasal Transmissible Venereal Tumour in a Dog. Int.J.Curr.Microbiol.App.Sci. 8(06): 1864-1867. doi: https://doi.org/10.20546/ijcmas.2019.806.222 